Revista NEP - Núcleo de Estudos Paranaenses, Curitiba, v.5, n.1, jun. 2019

Dossiê Partidos Políticos e Conexões Familiares

ISSN: $2447-5548$

\title{
O PROCESSO DE COLONIZAÇÃO DO EXTREMO NOROESTE DO PARANÁ E A REVOLTA DOS COLONOS DA AREIA BRANCA DO TUCUM
}

\author{
Maurílio Rompatto ${ }^{1}$ \\ Hortência Danielli Scaliante 2
}

\begin{abstract}
Resumo: O processo de colonização do Extremo Noroeste do Paraná foi empreendido a partir do ano de 1947 pelo Estado e por empresas colonizadoras como a companhia Terras Colonização Paranapanema Ltda., a Imobiliária Nova Londrina Ltda, a Colonizadora Marilena Ltda e a Colonizadora Norte do Paraná Ltda que deram origem às cidades como Nova Londrina, Marilena, Loanda (São Pedro do Paraná), respectivamente. Em janeiro de 1951 o Desembargador da Justiça do Estado do Paraná, João Alves da Rocha Loures, recebeu do governador Moysés Lupion uma área de 4.000 alqueires de terras na Areia Branca do Tucum quando a mesma já estava ocupada por colonos agricultores que possuíam títulos emitidos pelo estado e pelas empresas colonizadoras acima. Ameaçados de perderem suas terras para o Desembargador, os colonos se revoltaram no dia 14 de janeiro de 1964. Utilizando de documentos da Delegacia de Ordem Política e Social - Dops, o presente artigo apresenta uma análise de conjuntura dos acontecimentos que levaram à revolta dos colonos da Areia Branca do Tucum no Extremo Noroeste do Paraná.
\end{abstract}

Palavras-chave: grileiros; jagunços; colonos; revolta.

\section{THE COLONIZATION PROCESS OF THE NORTHWEST EXTREME OF PARANÁ AND THE REVOLT OF THE COLONIES OF WHITE TUCUM SAND}

\begin{abstract}
The process of colonization of the extreme northwest of Paraná was undertaken from 1947 by the State and by colonizing companies such as Terras Colonização Paranapanema Ltda., Imobiliária Nova Londrina Ltda, Colonizadora Marilena Ltda and Colonizadora Norte do Paraná Ltda. cities such as Nova Londrina, Marilena, Loanda (São Pedro do Paraná), respectively. In January of 1951 the Justice of the State of Paraná, João Alves da Rocha Loures, received from the governor Moyses Lupion an area of 4,000 alqueires of land in the White Sand of the Tucum when it was already occupied by farmers colonists who had titles emitted by the state and by the colonizing companies above. Threatened to lose their lands to the Judge, the settlers revolted on January 14, 1964. Using documents from the Political and Social Order Office - Dops, the president article analyze the conjuncture of the events that led to the uprising of the settlers of Areia Branca of the Tucum in the extreme northwest of Paraná.
\end{abstract}

Keywords: land thieves; gangsters; colonists; revolt.

1 - Doutor em História pela Unesp, Campus de Assis-SP (2004) e professor do colegiado de História da Unespar, Campus de Paranavaí-PR. Contato: mrompat to@gmail.com

2 - Licenciada em História pela Faculdade Estadual de Educação, Ciências e Letras de Paranavaí - FAFIPA (2001); pós-graduada em Educação ambiental e Estudos do Meio Ambiente pela FAFIPA (2002); Mestre em História pela Universidade Estadual de Maringá - UEM (2010) e atualmente é professora da rede pública de ensino do Estado do Paraná. Contato: hortencia_scaliante@ hotmail.com 
Revista NEP - Núcleo de Estudos Paranaenses, Curitiba, v.5, n.1, jun. 2019

\section{Introdução}

O recente processo de colonização do Estado do Paraná apresentou especificidades em cada nova região a ser "colonizada" ou (re)ocupada mas, de uma forma geral, essas novas regiões sofreram casos de violência e de conflitos ocorridos por disputas de terras. Estudando essas disputas entenderemos de que forma tais regiões se inseriram política e economicamente na história do Estado.

Apresentamos os casos dos grilos “Apertados" e "Areia Branca do Tucum” (19501970) para analisar como ocorreu o processo de colonização da região noroeste verificando quais foram os impactos que a ação colonizadora empreendida por empresas como a Companhia Brasileira de Viação e Comércio - Braviaco, Terras e Colonização Paranapanema Ltda, Colonizadora Marilena Ltda e Imobiliária Nova Londrina Ltda trouxeram para a região noroeste. Nesta região encontramos o cenário de disputas judiciais importantes, mas pouco conhecidas da maioria da população atual que a habita.

No transcorrer desses processos judiciais órgãos do governo estadual como o Instituto de Terras, Cartografia e Geociências (ITCG) e a polícia fizeram vistorias na região para coibir conflitos formando, em consequência disto, uma produção documental muito grande sobre o assunto: processos judiciais (civis e criminais) do Fórum da Cidade de Loanda, jornais da época, livros, arquivos da Delegacia de Ordem Política e Social/PR (DOPS).

Daremos voz àqueles que ajudaram a construir a história da região noroeste, pois vários protagonistas dos conflitos pela terra passaram a ser invisíveis para a memória oficial. Mostraremos quais foram os mecanismos de repressão ou conciliação utilizados pelo Estado para acabar com estas disputas.

Nos casos dos grilos “Apertados" e "Areia Branca do Tucum”, além das propriedades rurais, boa parte de uma população urbana perderia suas casas se aqueles que se diziam donos dessa área vencessem na justiça. $\mathrm{O}$ grilo Apertados abrangia uma área aproximada de 354.840 hectares ou 142.909 alqueires de $24.200 \mathrm{~m}^{2}$ abrangendo vários municípios como Paranavaí, Terra Rica, Guairaçá, Paranacity, etc., muitas destas cidades estão localizadas em parte da antiga concessão de terras da gleba Pirapó que o Estado do Paraná havia dado à empresa Braviaco, responsável por construir linhas férreas, mas o governo estadual depois revogou a concessão vendendo lotes de terra da mesma para empresas colonizadoras. 
Revista NEP - Núcleo de Estudos Paranaenses, Curitiba, v.5, n.1, jun. 2019

No caso do grilo Areia Branca do Tucum, as empresas: Terras Colonização Paranapanema Ltda, Empresa Colonizadora Marilena Ltda e Imobiliária Nova Londrina Ltda, somando uma área de 25.000 alqueires, tentavam estabelecer suas divisas com as do Estado ao mesmo tempo em que apareciam pessoas se dizendo donas dessas mesmas áreas; nisto, pessoas que já haviam comprado lotes urbanos e rurais nas áreas que abrangiam os atuais municípios Nova Londrina, Marilena, Loanda e São Pedro do Paraná (Porto São José) poderiam perder seus imóveis.

Mal resolvido as disputas entre os supostos donos desse grilo e as empresas colonizadoras surge outro problema: o Estado perdeu outras disputas por terras em diferentes regiões. O advogado João Alves da Rocha Loures, defensor dos vencedores, exigiu terras como forma de pagamento dos seus serviços. Acreditando que havia o total de terras que o Estado lhe devia na região noroeste Rocha Loures toma posse de uma área cujos limites confrontavam-se com os dos compradores das empresas já mencionadas. Inicia-se novamente conflitos na região pela posse da terra com denúncias de atos violentos.

\section{Breve história das concessões de terra no Paraná}

A partir da "Revolução" de 1930 Getúlio Vargas apostou na diversificação da produção industrial e agrícola do País e para que isto ocorresse ele lançou o projeto "Marcha para o Oeste" que além de promover a colonização do interior e das fronteiras do País, ajudaria na diversificação da produção agrícola.

O projeto era uma tentativa de preencher os "espaços vazios" na região centrooeste e fronteiriças pois, como fora visto na Primeira Guerra Mundial e com a política imperialista praticada por diversos países, era necessário proteger e "preencher" essas regiões menos povoadas.

Essa política tinha como objetivo principal, promover a ocupação dos vazios demográficos, por meio de absorção dos excedentes populacionais que faziam pressão no Centro-Sul do país, encaminhando-os para áreas que produziam matérias-primas e gêneros alimentícios a baixo custo, para dar subsídios à implantação da industrialização no Sudeste. Tentava-se, dessa forma, diminuir as diferenças econômicas regionais através da migração interna, aliviando, portanto, as tensões existentes entre esses regionalismos.

Porém, estes espaços tidos por "vazios" já se encontravam ocupados por pequenos produtores dispersos nestas áreas, ou tribos indígenas. Essas populações dispersas em áreas de baixa densidade demográfica passaram a sofrer pressões e violências exercidas por aqueles que souberam se aproveitar desse projeto varguista para justificar a apropriação das novas áreas de 
Revista NEP - Núcleo de Estudos Paranaenses, Curitiba, v.5, n.1, jun. 2019

expansão (SCALIANTE, 2010, p. 42).

A partir da "Revolução" de 1930 o grupo que estava no poder ligado ao cultivo da erva-mate e pecuária foi deposto, estes vão perdendo as facilidades de acesso à terra e surge uma nova elite que passa a se beneficiar das concessões de terras para colonização. Vargas destituiu o governo do Paraná e no dia 5 de outubro de 1930 foi nomeado como governador provisório do Estado o general Mário Tourinho, militar de carreira e irmão do comandante da Revolução no Paraná, Plínio Tourinho.

Mario Tourinho não conseguiu conciliar os interesses da antiga elite política ligada ao ex-governador com a que se formava; em consequência disso enfrentou sérias oposições ao seu governo renunciando em 29 de dezembro de 1931, sendo o cargo provisoriamente transferido a João David Pernetta (29/12/1931 a 30/01/1932), um representante da República Velha. Assim, Getúlio Vargas indicou Manoel Ferreira Ribas para interventor do Paraná que tomou posse no dia 30 de janeiro de 1932. Este era natural de Ponta Grossa e sua família fazia parte da classe dominante do Estado, mas teve uma carreira política no Rio Grande do Sul, tendo contato com Vargas antes da "Revolução", sendo, portanto, homem de sua confiança.

Ribas consegue se equilibrar no poder conciliando os interesses dos diferentes grupos políticos e, de acordo com Oliveira (2004, p. 27), houve uma "revisão e implantação de uma nova política agrária e de colonização fundiária. Algumas concessões do período anterior foram revistas. A concessão à Companhia de Terras Norte do Paraná e ao Engenheiro Beltrão foram também mantidas". Muitas empresas ou particulares que haviam conseguido concessões de terras para colonização não cumpriram as cláusulas que determinavam a colonização de parte dessas áreas. Por isto só manteve as concessões de terras nas quais foram cumpridas essa cláusula. Houve um intenso processo de fiscalização em terras particulares, públicas e concedidas e descobriu-se muitos grilos em todo o Estado, tanto nas áreas concedidas para colonização como em outras.

Desde Mario Tourinho algumas concessões já haviam sido revogadas como as que pertenceram a Companhia Estrada de Ferro São Paulo - Rio Grande por meio de sua subsidiária, a Braviaco, essa concessão de terras era chamada de gleba Pirapó e foi revogada pelo decreto n. ${ }^{\circ} 300$ de 3 de novembro de 1930 .

Assim, Ribas, aproveitando-se desta anulação autorizou o loteamento dessa área para vendas. Mesmo a Braviaco já iniciado a colonização de parte da gleba com a criação 
Revista NEP - Núcleo de Estudos Paranaenses, Curitiba, v.5, n.1, jun. 2019

da Fazenda Ivaí, muitas famílias, mesmo após a anulação da concessão, decidem ficar; porém, posseiros se instalam na região com a intenção de conseguir legalizar sua posse. Surgem os conflitos pela posse da terra. Desta forma, figuras polêmicas como o tenente Telmo Ribeiro e o tenente Aquiles Ferreira Pimpão, a serviço de Manoel Ribas, foram encarregados de impor a "ordem" na região expulsando os posseiros dessas áreas que estavam sendo "desbravadas".

Foi estipulado um prazo de 90 dias para que as pessoas regulassem suas posses, mas como muitos não tinham dinheiro para isso abandonavam suas terras; portanto, Ribas tomou a decisão de vender os lotes a preço mínimo onde as famílias poderiam tomar posse imediatamente da terra e depois pagar. Isto ocorreu devido ao estímulo do projeto federal "marcha para o oeste" que priorizava as pequenas propriedades rurais para dinamizar a economia e colonizar o interior.

Com o fim do Estado Novo e com a saída de Ribas do governo do Estado novamente ocorrem conflitos por terras, pois Moysés Lupion, novo governador (19471951), traz com ele novos grupos empresariais que passam a se beneficiar de concessões de terras em detrimento de pessoas que já se encontravam em áreas destinadas ao processo de exploração e colonização. Portanto, no primeiro mandato de Lupion, Telmo Ribeiro e Aquiles Pimpão continuaram a exercer sua influência na região noroeste.

Quando Bento Munhoz assumiu como governador (1951/1955) procurou intensificar a unidade territorial consolidando a identidade cultural do Estado; para isso procurou ligar a região norte à Curitiba. Também promoveu a criação de pequenos municípios para “[...] impedir a constituição de fortes poderes locais e o surgimento de políticas emancipatórias. Indiretamente, procurava-se fortalecer o poder político da capital” (KUNHAVALIK, 2004, p. 193). Mas, na prática, na questão dos conflitos pelas terras, favoreceu os grandes fazendeiros.

Quando Lupion retorna como governador (1956/1961), o problema de conflitos por terra intensificava-se, pois até terras já tituladas eram invadidas por posseiros ou grileiros. Neste contexto, a região noroeste também sofria com o problema de grilagens em áreas conhecidas como "Apertados" e "Areia Branca do Tucum”.

\section{O caso do grilo "Apertados"}


Revista NEP - Núcleo de Estudos Paranaenses, Curitiba, v.5, n.1, jun. 2019

O problema dessas terras que atingia os municípios de Paranavaí, Terra Rica, Nova Londrina e Loanda, segundo relatório apresentado pelo Instituto de Terras e Cartografia do Estado do Paraná (ITC - hoje denominado como Instituto de Terras Cartografia e Geociências - ITCG) surgiu através de um documento falso de sesmaria. Este relatório encontrado na pasta 02, narra o histórico do surgimento do grilo Apertados da seguinte forma:

\begin{abstract}
O imóvel 'APERTADOS', com a área aproximada de 354.840 hectares ou 142.909 alqueires de $24.200 \mathrm{~m} 2$, foi possuído de má fé por Fortunato José Peres Martins, João Martins da Silveira e Estanislau Israel da Silveira, que promoveram no Juízo de Tibagi, uma justificação de posse na qual, ouvindo 4 (quatro) testemunhas comprovaram... a legitimidade do título... (não existente) e a desnecessidade de revalidação ou legitimação do mesmo.

A 30/04/1892, foi julgada por sentença essa notável justificação.

Não tendo documento, com sisa paga anteriormente a 1854 , não havendo registrado a posse de conformidade com o Regulamento de 1854, os referidos posseiros passam, a prebenda, adiante e isso com celeridade, pois:

A 17/05/1892, por escritura pública, FORTUNATO JOSÉ PIRES MARTINS e sua mulher, por seu procurador, alienam uma terça parte do imóvel 'APERTADOS' a RODOLFO DE MACEDO RIBAS (fls. 35,39, 62, 74 e 77). A 18/05/1892, JOÃO MARTINS DA SILVEIRA e sua mulher, vendem a ANTONIO GUIMARÃES e CIRIACO DE OLIVEIRA BITTENCOURT, ${ }^{3} \mathrm{em}$ partes iguais, a terça parte que tinham na mencionada posse (fls. 40, 41, 42, 43 e 44).

A 18/05/1892, portanto na mesma data, ESTANISLAU ISARAEL DA SILVEIRA e sua mulher, vendem a JOSÉ TEIXEIRA PALHARES, a última terça parte da gleba 'APERTADOS' (fls. 45, 46, 47, 48, 49, 50, 51 e 52) (ITCG, s/d, p. 01).
\end{abstract}

Em 4 de julho de 1892 os proprietários deram entrada no tribunal de Tibagi a um pedido de divisão amigável do imóvel. Nos relatórios constam que o imóvel foi demarcado da seguinte forma:

\begin{tabular}{|l|r|}
\hline a) Rodolfo de Macedo Ribas & 47.636 alqueires \\
\hline b) Antonio Guimarães & 23.818 alqueires \\
\hline c) Ciriaco de Oliveira Bittencourt & 23.818 alqueires \\
\hline d) José Teixeira Palhares & 47.636 alqueires \\
\hline
\end{tabular}

(S/d, p. 2).

\footnotetext{
${ }^{3}$ Nesta pasta há vários relatórios sobre o assunto com cópias dos trechos dos processos das sentenças judiciais federais e estaduais, assim como referências de folhas de registros em cartórios das propriedades; alguns destes relatórios não apresentam datação e os nomes dos envolvidos apresentam grafias diferentes em algumas sílabas.
} 
Da mesma forma foram estabelecidos os limites e confrontações da área onde citase que começariam:

[...] a margem esquerda o rio Pirapó no lugar em que este rio faz barra com o rio Paranapanema, por este abaixo até a água do Tigre, no ponto de sua confluência, por este acima dividindo com terras de João Leite e Antonio Pereira Rocha, até as suas cabeceiras, e daí passando pelas cabeceiras do Ribeirão do 'Apertados' dividindo com terras de José Pereira da Rocha e José Benedito segue daí em rumo até encontrar o rio Pirapó, descendo por este abaixo margem esquerda até encontrar o ponto em que tiveram começo estas divisas (ITCG, s/d, p. 03).

Em 1898 o Estado do Paraná entra com uma ação no tribunal federal contra José Teixeira Palhares, Rodolfo de Macedo Ribas, Ciriaco de Oliveira Bittencourt, Dr. Jonas Babachisto Meira de Vasconcelos, Antônio Guimarães e suas mulheres para reaver as terras chamadas de "Apertados". A sentença foi julgada favorável para o Estado do Paraná onde o juiz federal, Dr. Manoel Ignácio Carvalho de Mendonça, reconheceu o domínio pleno do Estado sobre a gleba Apertados situada na Comarca de Tibagi, reconhecendo serem as terras devolutas e condenando os réus a restituírem ao Estado o imóvel. A sentença foi proferida no dia 25 de junho de 1898.

Como houve demora em se cumprir a sentença do tribunal federal e ocorrendo a morte de alguns dos réus surgem pessoas que se diziam seus sucessores reivindicando novo julgamento na questão. Alegavam que não haviam recebido as intimações para comparecerem nas audiências previstas para terem ciência da sentença.

Depois de alguns anos, o governo do Estado do Paraná fez concessão de parte desta área para a empresa Braviaco, responsável pela construção de linhas férreas. Em seguida, essa mesma concessão foi suspensa em 1930 e, depois de mais de uma década, em 1944 o Estado do Paraná criou a Colônia Paranavaí para lotear e vender essas terras à empresas colonizadoras para a finalidade de colonização.

Pelos relatórios do ITCG comprovou-se que a documentação apresentada pelos requerentes era falsa; os primeiros supostos donos: Fortunato José Peres Martins, João Martins da Silveira e Estanislau Israel da Silveira trataram de vender imediatamente as terras registradas no Cartório da cidade de Tibagi; em menos de um ano essas terras já foram divididas e vendidas para outras pessoas. Estes outros donos dividiram e revenderam essas terras a outras pessoas.

A documentação sobre essas revendas era um tanto quanto confusa e de difícil fiscalização, pois muitas negociações eram registradas em diversos cartórios, tanto no 
Revista NEP - Núcleo de Estudos Paranaenses, Curitiba, v.5, n.1, jun. 2019

Estado do Paraná como em cartórios de outros Estados. Por isso, em 1898 o governo do Paraná entrou na justiça para reaver as terras.

Os herdeiros de Antonio Guimarães, Ciriaco de Oliveira Bittencourt, Rodolfo de Macedo Ribas e José Teixeira Palhares não teriam direito à terra já que os citados haviam vendido suas propriedades para terceiros.

Antonio Guimarães teria vendido ao Dr. Jonas Babachisto Coelho Meira de Vasconcelos uma parte da gleba - 18.000 alqueires -, isto em 21/07/1892, restando 5.818 alqueires. Antonio Guimarães Filho seria seu único herdeiro.

Ciriaco vendeu à Companhia Marcondes a gleba que possuía área de 23.818 alqueires recebendo a quantia de $\mathrm{R} \$$ 40:000\$000 e o restante do preço da venda em notas promissórias emitidas pela empresa. No entanto, a Companhia Marcondes, como foi à falência e deixou de pagar as promissórias, desistiu dos seus direitos sobre a terra. Isto consta em escritura lavrada no dia $1 .^{\circ}$ de outubro de 1925 no livro número 01 folha 49 do Cartório do $3^{\circ}$ Ofício de Notas de Curitiba, segundo o relatório do Instituto de Terras e Cartografia do Estado (ITCG, s/d, p. 03).

O tenente cel. Rodolfo de Macedo Ribas havia hipotecado e vendido sua gleba com a área total de 47.636 alqueires. De acordo com o segundo relatório estudado sobre o assunto (este com carimbos com data de dois de fevereiro de 1950), Rodolfo de Macedo Ribas teria feito diversas operações com a mesma área.

Conforme se verifica da escritura pública lavrada no Cartório de Dolaricio Correa, a 12 de Agosto de 1927, Macedo Ribas hipotecou sua 'fazenda Apertados' ao cel. Arlindo de Castro pela respeitável quantia de $\mathrm{R} \$$ 2.138.100\$000, hipoteca essa que foi posteriormente reajustada pela Câmara de Reajustamento Econômico.

$\mathrm{Na}$ clausula 7a dessa escritura ficou esclarecido que da área total de 47.636 alqueires foi vendida uma parte de 12.000 alqueires a Jacinto Ferreira de Sá, por escritura pública de 29 de Agosto de 1923, lavrada em notas do 11 o Tabelião dr. Gabriel da Veiga da capital do Estado de São Paulo, Livro n 128, fls. 41 .

Ora, consoante se vê dessa escritura, Macedo Ribas era apenas possuidor, nessa época, de 35.636 alqueires, visto já ter vendido 12.000 alqrs. à Jacinto Ferreira de Sá.

Tendo mais tarde a Câmara de Reajustamento quitado a dívida hipotecaria de Ribas, ficou ele com o imóvel livre e desembaraçado, mas, posteriormente tornou a hipotecá-lo a Cristovão Ferreira de Sá, e, afinal, por escritura pública de ação 'in- solutum', de 24 de novembro de 1923, lavrada em notas do 110 Tabelião dr. Gabriel da Veiga, de São Paulo, Livro m.136, fls. 38, ficou sendo o dito Cristovão senhor e possuidor dos 35.636 alqueires.

Pelo exposto verifica-se que os herdeiros e sucessores de MACEDO RIBAS nenhum direito têm ao que ora pleiteiam (ITCG, 1950, p. 06-07, grifo nosso). 
Revista NEP - Núcleo de Estudos Paranaenses, Curitiba, v.5, n.1, jun. 2019

Depois, os irmãos Ferreira de Sá vendem ao Dr. Cústodio José Coelho de Almeida as terras adquiridas de Macedo Ribas; portanto, os herdeiros de Ribas não tinham direito às terras que reivindicavam. Por sua vez, o Dr. Custodio, após ter adquirido essas duas glebas, desistiu de seus direitos sobre elas reconhecendo os direitos do governo do Estado do Paraná, entrando em um acordo com o poder público e com a Companhia de Terras Norte do Paraná, já que parte desta área havia sido adquirida por esta Companhia do governo através de compra. Este acordo foi registrado no dia 16 de outubro de 1925, no $3^{\circ}$ Oficio de Curitiba.

José Teixeira Palhares teria vendido ao cel. Francisco Sanches Figueiredo uma área de 18.000 alqueires ficando com o restante, isto é, 29.636 alqueires. Consta no relatório que a viúva Figueiredo e demais herdeiros pleiteavam seus direitos relativos aos 18.000 alqueires e os senhores Dr. Luciano Nogueira e Felício Tarabay pleiteavam dentro desses 18.000 uma área equivalente a 8.000 alqueires que adquiriram por escritura de cessão de direitos de alguns dos herdeiros. Restavam ainda 29.636 alqueires que eram pleiteados pelos diretores do Banco Brasileiro de Descontos S/A, senhores José Alfredo de Almeida, Dr. José da Cunha Jr. e Amador Aguiar que haviam adquirido a dita parte restante dos herdeiros de Palhares.

Segundo o relatório, os únicos que poderiam pleitear direitos sobre o imóvel Apertados seriam: Antonio Guimarães Filho sobre 5.818 alqueires; herdeiros e sucessores de Sanches Figueiredo representados por seu advogado Dr. Prudente de Moraes Netto sobre 10.000 alqueires; Dr. Luciano Nogueira e Felício Tarabay, de uma parte adquirida de herdeiros de Figueiredo (8.000 alqueires). Tinham direitos os herdeiros e sucessores do Dr. Jonas Barachisto (ou Babachisto) sobre 18.000 alqs. e herdeiros e sucessores de Palhares, por seu advogado Dr. Heraldo Barreto sobre 29.636 alqueires.

Assim, não tinham direitos sobre as terras os herdeiros e sucessores de Ciriaco de Oliveira Bittencourt, os herdeiros e sucessores de Rodolfo de Macedo Ribas, os irmãos Ferreira de Sá e herdeiros do Dr. Custodio José Coelho de Almeida e os que se diziam filhos naturais de Palhares cuja investigação sobre a paternidade havia sido julgada improcedente pelo Supremo Tribunal Federal.

Em 1926, o Estado do Paraná, por meio de seu procurador, Dr. José de Miranda Valverde, alegando que o processo estava sem relator, pois que este havia falecido, requereu ao ministro presidente a designação de novo relator e a renovação da instância pedindo a intimação do suplicado, na pessoa de seu advogado e procurador judicial. Foi 
Revista NEP - Núcleo de Estudos Paranaenses, Curitiba, v.5, n.1, jun. 2019

nesse mesmo ano que Cristovão Ferreira de Sá e Jacinto Ferreira de Sá ingressaram no processo alegando serem os sucessores de cel. Rodolfo de Macedo Ribas e sua mulher. Mas, como apontavam os documentos do ITCG, estes haviam vendido suas terras para Custódio José Coelho de Almeida. A nova sentença só foi publicada por meio de um acórdão datado de 16 de outubro de 1930 e publicado em 11 de maio de 1931.

Em 1949, o Estado do Paraná requereu a execução do julgado pedindo que fossem expedidas cartas precatórias para as comarcas de Tibagi, Apucarana e Mandaguari para que se procedessem aos cancelamentos das transcrições territoriais dos réus.

O processo se arrastou e afinal, o Dr. Juiz atendeu a alegação de prescrição da execução, alegada por todos os embargantes, por sentença datada de 28 de junho de 1951 (fls. 768-778).

Houve apelação por parte do Estado (fls. 784-799), e por parte da sociedade Pastoril e Agrícola Ferreira e Toledo Pizza Ltda (fls. 7999-817, 4o vol.).

O Egrégio Tribunal de Justiça, julgando os recursos, por maioria dos votos, julgou- se incompetente, por entender que era competente o Egrégio Tribunal Federal do recurso (fls. 997-999 v.), datado o v. acórdão de 6 de fevereiro de 1954.

[...]. Enquanto procedia a execução da sentença com variadíssimos embargos, os herdeiros do cel. Rodolpho de Macedo Ribas e sucessores de José Teixeira Palhares, ingressavam em Juízo, com artigos de atentado, sob a alegação de que o Estado do Paraná sem que houvesse promovido a execução de sentença titular a inúmeras áreas de terras compreendidas nos quinhões 3 e 4 da Fazenda 'Apertados'. Os artigos de atentado foram processados e julgados procedentes; houve recurso para o Tribunal que reformou a sentença da primeira Instancia; em embargos, julgou-se o Egrégio Tribunal incompetente para decidir, de vez que se tratava de feito decidido no Juízo Federal e que competente era o Egrégio Tribunal Federal de Recursos; o Colendo Supremo Tribunal Federal, negou ou melhor, não conheceu do Recurso Extraordinário interposto e determinou a remessa do processo ao Tribunal Federal de Recursos. Este julgou, por fim as apelações, negando provimento por maioria, em embargos, foi o acórdão, em 31 de agosto de... (ilegível... volume dos autos de atentado), confirmado (ITCG s/d, p. 09).

Um dos maiores problemas referentes a esta disputa é que a ação de atentado iniciada por Arthur Borges Maciel Filho que se dizia dono de uma área de 6.500 alqueires e que teria adquirido esta área de José Teixeira Palhares por meio de procuração em causa própria foi julgada procedente, ou seja, o governo do Estado não poderia ter vendido os títulos e lotes das terras em litígio.

O processo relativo ao Incidente de Atentado permaneceu estacionário na 1a Vara dos Feitos da Fazenda Pública, atual 15a Vara Cível, após o E. TER haver determinado o cumprimento de seu acórdão, que determinava a reposição de lide ao status quo ante. Esta reposição somente seria possível mediante o despejo judicial de toda a massa humana (estimada, em levantamento feito em 1952 pelo saudoso Desembargador Antonio Franco Ferreira da Costa em função de Correição requerida contra o MM. Juiz que não via como efetuar aquela reposição, em cerca de meio milhão de pessoas). Todavia, em face da 
Revista NEP - Núcleo de Estudos Paranaenses, Curitiba, v.5, n.1, jun. 2019

determinação do TER, o MM. Juiz se viu compelido a decretar o aludido despejo. Este está, entretanto, na dependência do cumprimento de algumas formalidades processuais por parte dos psêudos proprietários da Fazenda "Apertados", como, verbi gratia, a indicação precisa e nominal de todos os despejados e respectivos lotes para a indispensável expedição de Carta precatória às Comarcas de Paranavaí, Terra Rica, Nova Londrina e Loanda. Os interessados, entretanto, relutam em fazer tal indicação, alegando que os elementos se encontram todos no processo. Daí a paralização do feito por vários anos, até que o mesmo foi removimentado pelo novo juiz titular da 15 . $^{\text {a }}$ Vara Cível. Na oportunidade da removimentação aludida, os interessados, intimados por oficio a S. Paulo, manifestaram interesse no prosseguimento do feito. Após isto, o Estado do Paraná, em data de 9 de junho de 1969, requereu a prescrição intercorrente do feito, pelas sucessivas paralisações devidas aos próprios interessados, demonstrando, com farta documentação, a total e absoluta impossibilidade de despejo de área tão vasta, tão populosa, para uma impossível 'reposição da lide ao estado anterior', bem ainda que a consequência legal do deferimento do atentado não é o despejo, consoante se vê na Lei e no entendimento dos jurisconsultos, lamentavelmente, porém, o MM juiz não deferiu, nem indeferiu, até o momento, 26/10/1970, a prescrição requerida que procede e tem o apoio na Lei e jurisprudência (ITCG s/d, p. 10).

Arthur Borges inicia uma ação de demarcação e divisa dessa área no tribunal da comarca de Nova Londrina; caso ganhasse, as pessoas seriam despejadas de suas casas e propriedades rurais. Além disto, o Estado teria que indenizar essas pessoas já que a área foi loteada e vendida para as empresas colonizadoras pelo mesmo. No ano de 1972, mesmo o juiz de Direito da 1. ${ }^{a}$ Vara da Fazenda Pública ter dado ganho de causa ao Estado do Paraná, Francisco Bonini também se apresenta na qualidade de sucessor de José Teixeira Palhares e de Rodolfo de Macedo Ribas, ingressando com apelação contra a decisão. Diante deste fato, o Estado novamente recorreu como se explica a seguir:

[...] O Estado do Paraná, em 14/04/72, ofereceu contrarrazões de apelação sobre as duas apelações esclarecendo que o processo de atentado não tem autonomia de execução, não podendo ser executado diretamente, porque apenas constitui e manda preceito cominatório ou sob responsabilização civil em perdas e danos, mas tão somente na ação principal ou em ação própria se pode condenar em perdas e danos decorrentes do atentado e que nunca se poderia pretender a reposição da lide ao seu estado anterior, decorridos vinte e dois (22) anos da sentença proferida nos autos de atentado, pela forma de despejo da área que comporta hoje sete (7) municípios, três (3) comarcas e com uma população de cerca de mais de meio milhão de habitantes, em favor de quem nunca ali possuiu ocupação alguma e nada fez para o desenvolvimento da região (ITCG, s/d, p.12-13).

O que ajudou o Estado foi que os títulos sobre essa área foram julgados viciosos desde sua origem, na primeira sentença em 1898. Quanto a Arthur Borges de Maciel Filho e Francisco Bonini, o promotor público protestou nos autos do processo alegando que ambos não teriam condições de representar José Teixeira Palhares e que a documentação 
Revista NEP - Núcleo de Estudos Paranaenses, Curitiba, v.5, n.1, jun. 2019

apresentada por estes era falsa, que a documentação apresentada por Arthur como sendo herdeiro de José Teixeira Palhares foi considerada irregular (JORNAL O ESTADO DO PARANÁ: 04 Maio 1976, arquivado no memorial do processo civil de desapropriação ${ }^{\circ}$ $2.175 / 64$ vol. 07).

Arthur Borges só havia ganho a ação judicial de atentado, porque esta foi julgada separada do processo original. Desta forma, quando o Estado apresentou seus argumentos, o juiz que havia dado ganho de causa a Arthur compreendeu que ambas as causas eram uma só e revogou a sentença favorável a ele em 10 de maio de 1976 deixando sem efeito o mandato que determinava a execução do despejo nas comarcas de Paranavaí, Loanda, Nova Londrina e Terra Rica. Depois de se arrastar na justiça por muitos anos, em 1978 é proferida a decisão judicial favorável ao Estado como detentor dos títulos do imóvel "Apertados".

Mapa do noroeste do Paraná: em destaque a área do grilo "Apertados” com 142.909 alqueires

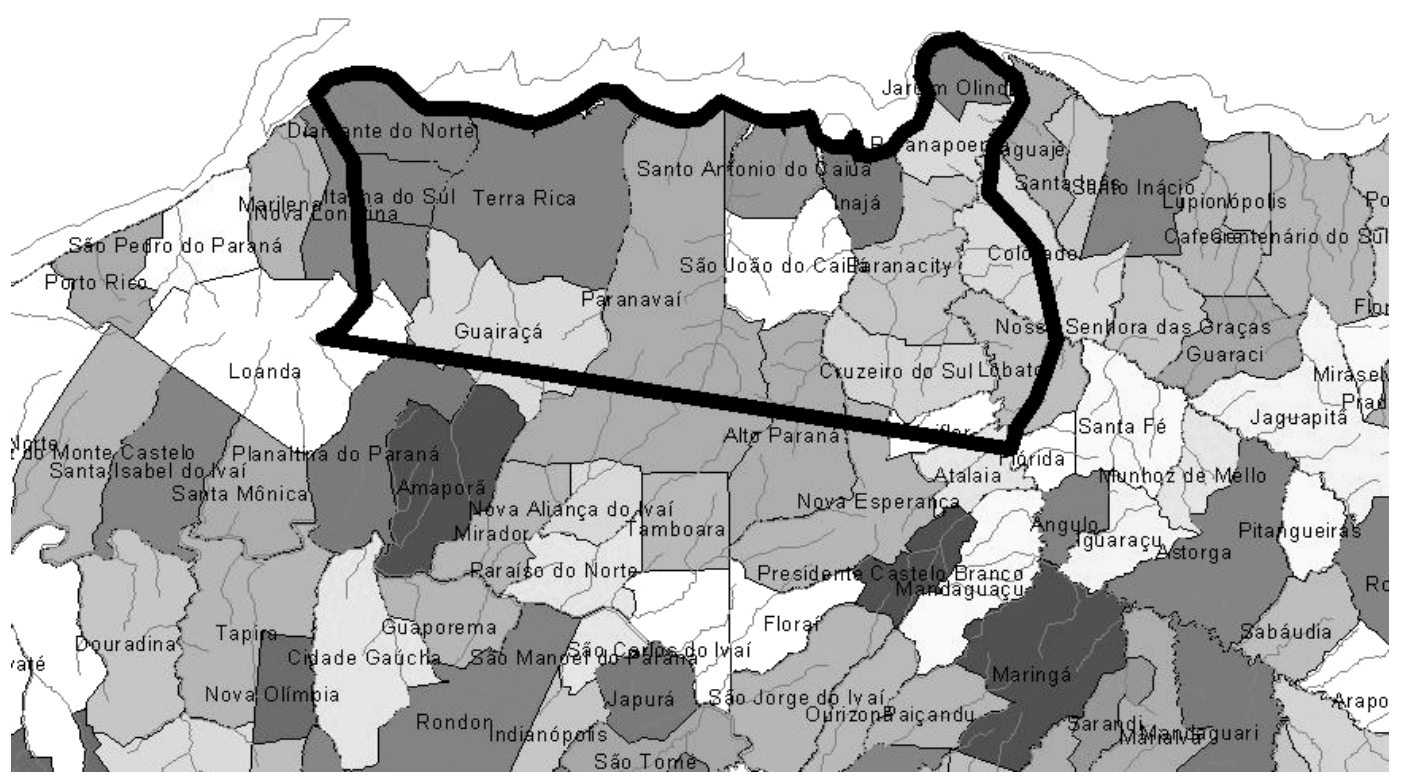

Fonte: EMATER - Mapa “Municípios do Paraná” (Adaptada por Belmiro Ruiz Marques).

No ano de 1950, quando se tentou por sua legitimidade no cartório da comarca de Mandaguari, o grilo "Apertados" - conforme o mapa acima - atingia uma enorme área da Colônia Paranavaí correspondente aos atuais municípios de Loanda, Nova Londrina, Itaúna do Sul, Diamante do Norte, Guairaçá, Terra Rica e Paranavaí além de outras localidades fora da Colônia como: Alto Paraná, Nova Esperança, Uniflor, Cruzeiro do 
Revista NEP - Núcleo de Estudos Paranaenses, Curitiba, v.5, n.1, jun. 2019

Sul, Inajá, Paranacity, Santo Antônio do Caiuá, São João do Caiuá, Colorado, Itaguajé, Lobato, Paranapoema e Atalaia.

\section{O caso do grilo "Areia Branca do Tucum"}

De acordo com os relatórios do Instituto de Terras, Cartografia e Geociências (ITCG), esse grilo se originou de uma carta de sesmaria expedida em 24 de março de 1786. Seriam seus proprietários os irmãos Antonio, Francisco, João, José e Manoel Ferreira Simões. Corresponderia a três léguas de terras em quadra, a cada um, nas paragens "Areia Branca do Tucum", no Distrito da Vila de Curitiba, nas margens dos rios Paraná e Paranapanema. Observamos aqui a falta de informações mais precisas nesta carta de sesmaria.

Verificou-se que houve um período de lacuna entre a carta de sesmaria e a escritura particular passada em 22 de dezembro de 1849 por Serafim Ferreira de Andrade e sua mulher que se diziam donos do imóvel por posse feita no ano de 1847 . Venderam a João Antônio de Assis, mas Serafim não provou ser o sucessor dos irmãos Simões como também não vinculou à escritura de venda a sesmaria de 1786. Os limites e confrontações seriam os seguintes:

\footnotetext{
Principiando na barra do Rio Tigre no Rio Paraná, por este abaixo até a barra do ribeirão Areia Branca do Tucum, também no Rio Paraná, e daí subindo pela Areia Branca acima até suas últimas cabeceiras abrangendo as vertentes da margem direita e de lá em rumo linha reta procurando as últimas cabeceiras do ribeirão do Tigre e descendo PR até abaixo abrangendo todas as suas vertentes da margem esquerda até o Rio Paraná, compreendendo todas as águas vertentes dentro dessas divisas (ITCG, s/d, p. 01).
}

Novamente, nas investigações a respeito das vendas e novas divisões da área em disputa pelo Estado e pelos grileiros, observamos que os documentos apresentam divergências de datas, nomes, ou mesmos nomes com grafias diferentes em alguma sílaba e a utilização de diferentes cartórios, até mesmo de outros Estados.

24.03.1786 - Carta de Sesmaria, passada em favor dos irmãos Francisco, Antonio, João, José e Manoel Ferreira Simões:

22.12.1849 - Escritura particular, através da qual Serafim Ferreira de Andrade e s/mulher vendeu o imóvel a João Antonio de Assis, transcrita em 13 de julho de 1932, no Cartório, Arestides Vicente Maio, escrivão de Paz e Tabelião do distrito de Nuretama, Comarca de Palmital do Município de Ibirema, Estado de São Paulo, ás fls. Noventa e nove e verso do livro no 06. 
Revista NEP - Núcleo de Estudos Paranaenses, Curitiba, v.5, n.1, jun. 2019

29.05.1851 - Escritura particular através da qual Joaquim Nunes da Silva e s/mulher, vendem o imóvel a João Antônio de Assis, transcrita sob no 2.068 em 21 de outubro de 1926 no livro no 2 de Registro de Fianças, declarações e Escritura do Cartório Amaral Gurgel da Comarca da Capital do Estado de São Paulo.

15.01.1860 - Escritura particular, através da qual João Antônio de Assis e s/ mulher, vende o imóvel a Pantaleão Manoel, registrada as fls. 49 do livro no 1 do cartório do Registro Civil, de Conceição de Monte Alegre, Comarca de Paraguaçu Paulista, Estado de São Paulo.

21.07.1893 - Escritura Pública passada as fls. 43 do livro no 5 do Cartório do

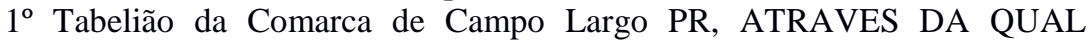
Pantaleão Manoel, vende o imóvel com a área de 25.000 alqueires a João Severino Porto.

07.04.1934 - Procuração em causa própria passada por João Severino Porto a Albano David com poderes para dispor da forma que entender do imóvel Areia Branca do Tucum, as fls. 83 do livro no 8 do Cartório do Escrivão distrital Attílio Caldeiraro, em Nova Bassano Estado do Rio Grande do Sul.

20.04.1934 - Substabelecimento de procuração em causa própria outorgado por Albano David e s/ mulher ao Sr. Valencio de Oliveira Xavier, lavrado naquela data pelo Tabelião do 2o Oficio Homorino Malheiros de Passo Fundo Estado do Rio Grande do Sul, pela qual mediante o recebimento da quantia combinada, aqueles outorgantes substabeleceram a estes outorgados todos os poderes sem reserva, que lhes foram outorgados por João Severino Porto, em 07.04.1934, referente à Fazenda 'Areia Branca do Tucum'.

27.09.1946 - Escritura pública de promessa de venda que faz João Severino Porto, por seu procurador em causa própria Albano David, de um lado como outorgante e de outro Felipe Oliveira Licht e Carlos Lima Santos, como outorgados para venda aos segundos da área de 15.000 alqueires de terras da Fazenda 'Areia Branca do Tucum' na Comarca de Tibagi, Estado do Paraná com limites e confrontações descritos no corpo da escritura, a qual foi lavrada as fls. 96v do livro no 264 do 130 Oficio de Notas Mario Queiroz da cidade do Rio de Janeiro.

02.05.1949 - Através de escritura pública, nessa data lavrada no $3^{\circ}$ Tabelião da cidade de Londrina, João Severino Porto, por seu procurador vendeu;

a) para Terras Colonização Paranapanema Ltda a área de 18.750 alqueires;

b) para Jeny dos Santos David e Chahir Artur David a área de 6.250 alqueires. 16.08.1950 - Através Escritura pública lavrada nas Notas do 1o Tabelião de Londrina, Jeny dos Santos David e Chahir Artur David, venderam a empresa Colonizadora Marilena Ltda, a área de 4.250 alqueires, e a Imobiliaria Nova Londrina Ltda, a área de 2.000 alqueires (ITCG, s/d, p02-03, grifo nosso).

Na citação acima demonstramos que houve duas vendas para João Antonio de Assis: uma feita por Serafim Ferreira de Andrade e outra feita por Joaquim Nunes da Silva; e isto ocorreu em cartórios de localidades distintas evidenciando, portanto, a primeira fraude em relação à venda do imóvel; outro fato é que se menciona a venda, mas não a quantidade dos alqueires.

João Antonio de Assis vendeu para Pantaleão Manoel e aqui menciona-se os alqueires; este vende para João Severino Porto que, por meio de uma procuração, transferiu para Albano David poderes para dispor como quisesse do imóvel. Este, por sua vez, repassou para o senhor Valencio de Oliveira Xavier os poderes referentes à venda ou compra das terras. 
Revista NEP - Núcleo de Estudos Paranaenses, Curitiba, v.5, n.1, jun. 2019

Novamente aparece João Severino Porto que, através de Albano David, institui por meio de uma escritura pública a promessa de venda de parte (15.000 alqueires) do imóvel aos senhores Felipe Oliveira Licht e Carlos Lima Santos; tal fato aparece registrado em um cartório do estado do Rio de Janeiro. Depois, João Severino Porto, por meio de Albano David, vendeu uma parte das terras para a empresa Terras Colonização Paranapanema Ltda e outra parte para Jeny dos Santos David e Chair Artur David; estes últimos venderam sua parte para a Empresa Colonizadora Marilena Ltda e para a Imobiliária Nova Londrina Ltda. As três empresas somavam uma área de 25.000 alqueires que tentavam regularizar estabelecendo as divisas com as terras que seriam do Estado do Paraná.

A empresa Terras Colonização Paranapanema Ltda protocolou (protocolo $\mathrm{n}^{\circ}$ 8.522 de 27/06/1949 P.G.) o pedido de regularização requerendo que, através de Órgão Técnico competente e através da Consultoria Geral do Estado, se lavrasse o termo de autenticação de trabalhos e aprovação do loteamento, localização de patrimônio e planejamento das cidades com a transposição dos memoriais descritivos para servir de documento para assim receber as certidões devidas. O Departamento de Geografia, Terras e Colonização - DGTC - e a Consultoria Geral do Estado, após várias diligencias, emitiram um parecer favorável para a empresa.

Os relatórios da $11^{\mathrm{a}}$ Inspetoria de Terras informaram "que na área encontravamse posseiros, mas que os mesmos estavam ali em acordo com a empresa em virtude de compromisso de compra e venda feito com a empresa, e que muitos já possuíam benfeitorias e culturas em formação”. Mas, apesar do parecer positivo, o DGTC informou que a área era disputada por Valencio de Oliveira Xavier que, por petição datada de 02 agosto de 1950 (prot. nº 10.769 de 8 Ago. 1950), havia pleiteado um acordo com o Estado. Os outros eram as empresas Terras e Colonização Paranapanema Ltda, Empresa Colonizadora Marilena Ltda e Imobiliária Nova Londrina Ltda e que todos os requerentes haviam juntado documentos para comprovar suas alegações.

Seria a certidão de compra e venda onde Serafim Ferreira de Andrade e sua mulher Anna Pires de Andrade teriam vendido a João Antonio de Assis terras situadas próximas ao Rio Paraná, de nome “Areia Branca do Tucum”, cuja escritura apresentava os limites e confrontações aqui já expostas. Anexaram também todos os históricos de vendas da mesma área até chegar a João Severino Porto.

Na relação dos documentos apresentados até: 
[...] a penúltima transação, isto é, até a venda feita por Pantaleão Manoel e sua mulher a João Severino Porto, há, ao que tudo indica, concordância entre os vários interessados no expediente em exame quanto à origem dos seus alegados direitos. Divergem, no entanto, esses interessados a partir desse ato, pois tanto Valencio de Oliveira Xavier como as empresas requerentes arrogam-se o domínio sobre as terras em questão. Daí por que achamos que a atitude do poder público, em face dos pedidos constantes do processo, não poderá beneficiar em detrimento daquelas (ITCG, s/d, p. 11-12).

No relatório do Instituto de Terras e Cartografia - ITCG - foi citado que "não havia prova da ilegitimidade dos títulos" das empresas interessadas em regularizar as terras adquiridas e, portanto, João Severino Porto não tinha direito sobre as mesmas já que havia vendido para diversos compradores e nem ao Estado essas terras pertenciam já que o mesmo, durante cinquenta anos, não se manifestou sobre as mesmas e ainda recebeu os impostos de transferência sobre as terras.

[...] deverão ser incluídas no termo de autenticação, pelo menos duas clausulas, por nós reputadas essenciais: uma, na qual se delcace que a mesma autenticação é feita em consequência exclusiva do fato de serem desconhecidas nesta ocasião, pelos órgãos administrativos ouvidos na processo, as provas da ilegitimidade dos títulos apresentados pelas empresas requerentes se tais provas existirem; a segunda, na qual se declare a autenticação absolutamente não excluirá quaisquer direitos de terceiros entre quais Valencio de Oliveira Xavier, se tais direitos lhes reconhecido pelo Poder judiciário. Finalmente, se o Governo entender oportuna e necessária a autenticação, deverá o processo ser encaminhado, para esse fim, ao Departamento de Geografia, Terras e Colonização, para as providencias regulamentares, como consequência da assinatura do termo de autenticação, deverão as partes requerer a desistência da ação possessória, se assim o entender o Governo do Estado nos termos do art. 9. ${ }^{\circ}$ da lei no 236, de 19 de agosto de 1949. Nessas condições a Consultoria Geral só poderá efetivar essa desistência com autorização expressa do Chefe do Poder Executivo Estadual que a poderá outorgar, mediante a aprovação deste parecer [...] (ITCG, 1952, p. 15).

O parecer foi analisado e no dia 8 de janeiro de 1951 Lupion assina o despacho sendo o mesmo encaminhado ao DGTC que lavrou o termo de autenticação. Ocorreu a desistência da "ação de manutenção de posse". A titularidade das empresas foi validada, pois o que consta é que Valencio de Oliveira Xavier recebeu uma procuração de Albano David para dispor da área como quisesse e ainda consta que o próprio João Severino Porto, através de Albano David, vendeu esta área para as empresas colonizadoras. Restava saber se a procuração de Valencio de Oliveira Xavier seria validada também.

Depois surgiram outros que se diziam ‘procuradores' de João Severino Porto que, com base em um levantamento feito por um engenheiro civil sem nenhuma assistência do Estado, requereram ao Juíz de Direito da Comarca de Mandaguari para que, ao lado da 
Revista NEP - Núcleo de Estudos Paranaenses, Curitiba, v.5, n.1, jun. 2019

transcrição do termo de autenticação das empresas, fosse feita a averbação de mais de 52.000 alqueires. Essa nova área foi inserida dentro dos 25.000 alqueires resultando em conflitos, pois esses falsos procuradores invadiam propriedades dentro dessa área alegando serem suas por terem procurações no nome do antigo titular João Severino Porto.

A dilatação da área respectiva de 25.000 para 77.000 alqueires implicava em invasão de terras do estado do Paraná. O governo,

\footnotetext{
por intermédio de sua Secretaria da Fazenda, baixou a Portaria n ${ }^{\circ} 53$, em 20 de fevereiro de 1951, visando impedir a alienação como se fossem de domínio privado, dos 52.000 alqueires de terras devolutas, sob o pretexto de constituírem o excesso resultante da averbação do título "Areia Branca do Tucum", pretendiam vender (ITCG, 1952, p.17).
}

A polícia passou a proibir os pequenos agricultores de efetuarem as colheitas ou lida de gado até comprovarem seus títulos; assim, as empresas colonizadoras encaminharam para o governador os protocolos pedindo que fossem suspensas as ordens proibitivas em relação aos agricultores, fornecendo certidões negativas e talões de sisa (designação recebida naquela época para o imposto de transmissão de propriedades) correspondentes aos lotes de terras que haviam sido vendidas para esses pequenos proprietários.

Os pedidos das empresas não foram atendidos, mas ocorreu uma diminuição da violência nas proximidades das cidades de Marilena e Nova Londrina devido ao policiamento reforçado que visava impedir novas invasões por grupos de grileiros que se diziam compradores das terras de João Severino Porto.

Somente em 1976 é que a situação referente aos procuradores de João Severino Porto ficou resolvido. Nas investigações apurou-se que os demais que se apresentaram como procuradores ou compradores de João Severino Porto haviam apresentado documentos falsos. Quanto a Valencio de Oliveira Xavier, o mesmo não teve sua procuração reconhecida.

As empresas prosseguiam nos trabalhos de colonização com a abertura de estradas, estruturação urbana das cidades de Nova Londrina e Marilena. Porém, neste mesmo período surge a figura de João Alves da Rocha Loures que havia adquirido terras nessa área, nas proximidades da cidade de Porto São José e passou a requerer posses de pequenos proprietários dizendo que lhe pertenciam. 
Revista NEP - Núcleo de Estudos Paranaenses, Curitiba, v.5, n.1, jun. 2019

João Alves da Rocha Loures era advogado desde 1924 e especializado em questões fundiárias. Exerceu o cargo de Juiz de Palmas e depois em Clevelândia abandonando-o para retornar à atividade advocatícia. Fazia parte do grupo de poder político daquela época liderado por Affonso Alves de Camargo, Presidente do Estado (1926-30). Também foi professor em 1937 assumindo a Cátedra de Ciências das Finanças da Faculdade de Direito da Universidade do Paraná.

Após o fim do Estado Novo participou do processo de redemocratização e, dessa forma, inseriu-se no grupo de políticos da legenda do PR (Partido Republicano) que resultou na eleição de Bento Munhoz da Rocha Neto como Governador em 1950. Assim, na década de cinquenta, exerceu o mandato de Deputado Federal (1951-52) sendo nomeado Desembargador do Tribunal de Justiça (1952). Foi candidato ao Senado Federal em 1954, mas não conseguiu ser eleito.

Os proprietários daquela área aguardavam o documento definitivo de domínio dos órgãos estaduais e somente em 1976 é que o Estado emitiu um título provisório para os proprietários quando decidiu pela desapropriação da área em favor dos que ali haviam adquirido seus lotes através das empresas colonizadoras.

O Estado deu início ao litígio com Rocha Loures em relação à questão do valor da indenização devida ao mesmo. Loures alegava que havia feito as "benfeitorias" na área, mas o advogado do Estado procurava provar que quem havia trabalhado na terra tinha sido os pequenos proprietários que haviam adquirido as terras antes de Loures.

João Alves da Rocha Loures havia defendido várias causas referentes à disputas por terras tendo ganhado muito delas e aqueles que o haviam contratado, em alguns casos, o pagavam com parte das áreas que haviam conseguido.

Um destes casos defendidos por Rocha Loures referia-se à Braviaco. Foi uma ação possessória que esta empresa moveu em 1927 perante a Justiça Federal contra os irmãos Jacinto e Christovam Ferreira de Sá, com área superior a cem mil alqueires, que abrangia o "grilo" denominado "Apertados". Loures ganhou a causa ante o Juiz da Secção do Paraná cuja sentença foi confirmada pelo Supremo Tribunal Federal (CARTÓRIO CIVIL DE LOANDA, 1964, p. 03).

Em pagamento aos seus honorários profissionais a Companhia autorizou-o a tomar posse da "fazenda Tabajara" com área de 3.000 alqueires. Mas o Governo do Estado, na época o interventor Manoel Ribas, entendeu que o título de domínio da Companhia estava nulo e, como tal, o declarou; passando, ato contínuo, a lotear e vender 
imóveis a terceiros.

Depois, Rocha Loures foi advogado de Arno Feliciano de Castilho e sua esposa e de Lisbella de Souza Franco, viúva e única herdeira de Antônio Franco Sobrinho, os quais sucediam a Braviaco, pois haviam arrematado em leilão parte do seu acervo. Loures, por volta de 1948, promoveu uma ação divisória do imóvel composto de duas partes de terras: uma a Fazenda Tabajara com 3.000 alqueires e outra denominada "Gleba $\mathrm{n}^{\circ} 01$ " com 2.000 alqueires requerendo, conforme o artigo 631 do antigo Código Civil, que fosse declarado o domínio de seus clientes e a invalidade do ato de força do Interventor que os despojara do imóvel. A ação foi julgada procedente pelo juiz da comarca de Apucarana, Alceste Ribas de Macedo, e a sentença foi confirmada pelo Tribunal de Justiça.

Em pagamento pelos seus honorários, Arno Feliciano de Castilho com sua esposa e Lisbella de Souza Franco lhe transferiram, cada um, quinhentos alqueires, os quais Rocha Loures alienou ao fazendeiro Remo Massi. Porém, algumas dessas áreas já haviam sido loteadas e vendidas para terceiros pelo Estado. Em consequência disto, Rocha Loures entrou na justiça para que houvesse uma reparação para ele e seus clientes. O Estado foi sentenciado pela justiça a compensar os reclamantes com outras áreas em outras partes de seu território onde houvesse terras disponíveis. Seus clientes receberam as áreas devidas e Rocha Loures aguardava a disponibilização da área que lhe era devida (CARTÓRIO CIVIL DE LOANDA, 1964, p. 09).

Rocha Loures ganhou mais uma causa de um imóvel denominado de "Covozinho" recebendo como pagamento uma área de mil alqueires aos quais ajuntou com o restante que o Estado lhe devia; assim, o então governador Adolpho de Oliveira Franco (25/07 a 31/10/1949) encaminhou a solicitação de autorização de posse para Assembleia Legislativa (CARTÓRIO CIVIL DE LOANDA, 1964 p. 04).

Área do grilo “Areia Branca do Tucum” de mais de 52 mil alqueires paulistas, nos atuais municípios de Nova Londrina, Marilena, Loanda e São Pedro do Paraná 


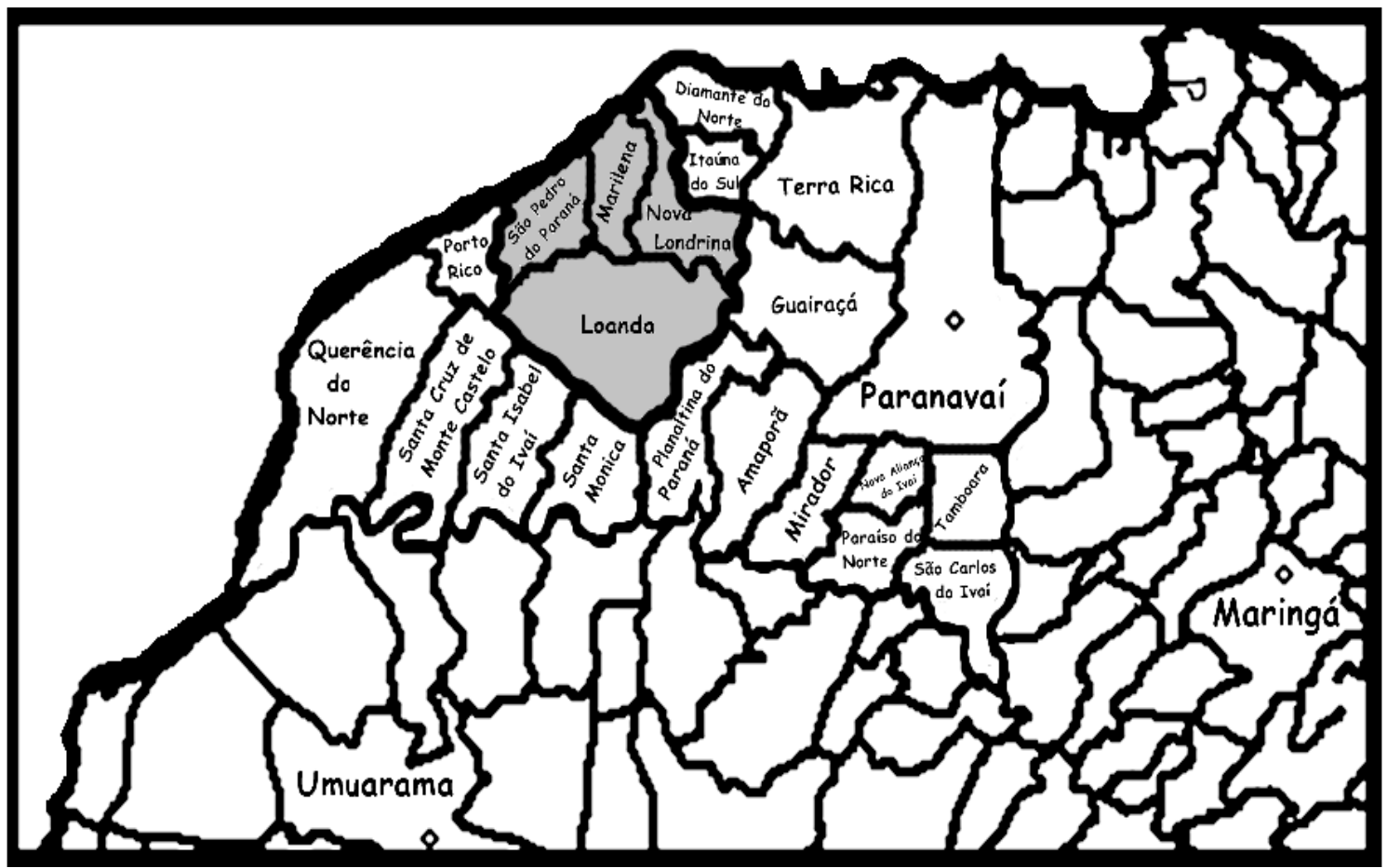

Fonte: EMATER (Adaptada por Brenda Rompatto)

Em 8 de janeiro de 1951 o governador Moysés Lupion enviou a Areia Branca do Tucum uma comissão militar para demarcar 1.200 alqueires de terras para o Desembargador Rocha Loures na localidade de Porto São José e também de uma outra área totalizando 4.000 alqueires que ele reivindicava judicialmente na região e que o Estado lhe devia desde 1926, quando este perdeu disputas de terras para grileiros em outras regiões do Paraná e o então advogado Rocha Loures, defensor dos vencedores, exigiu terras como forma de pagamento de seus honorários.

Assim, dando cumprimento à requisição do Juízo da Fazenda Estadual ao Coronel Albano D’Ávila, chefe de polícia em Londrina, foi designado um contingente militar para o Porto São José para garantir a emissão dessa área de 1.200 alqueires ao Desembargador à margem do Ribeirão Areia Branca do Tucum. Segundo relatório do próprio delegado especial, Coronel João Batista Lopes, designado para a missão, se verificou que, já naquela época, existiam mais ou menos 200 famílias de colonos em toda área de mais de 4.000 alqueires da Areia Branca do Tucum reivindicada pelo Desembargador e muitas delas possuíam títulos expedidos pela imobiliária Terras Colonização Paranapanema Ltda.

Em 1955, o assistente técnico do DGTC, em informação prestada no processo protocolado sob $\mathrm{n}^{\circ} 10.560 / 55$, declarou só haver aqueles 1.200 alqueires disponíveis na 
Revista NEP - Núcleo de Estudos Paranaenses, Curitiba, v.5, n.1, jun. 2019

Colônia Paranavaí e esclareceu que os 3.000 mil alqueires restantes da área pretendida por Rocha Loures poderiam ser localizados em outras áreas devolutas do Estado. No mesmo ano, o Coronel João Batista Lopes retornou à região já como Delegado Regional de Paranavaí e constatou na época, a existência de pelo menos 500 famílias com casas residenciais, comerciais, formação de cafeeiros e pastagens em toda aquela vasta região, a qual achava-se em pleno progresso (ESTADO DO PARANÁ, 1964).

Porém, mais tarde, em 1956, o mesmo técnico do DGTC alegou que a área pretendida por Rocha Loures na Areia Branca do Tucum poderia ser ampliada para 4 mil alqueires sobre terras da gleba 21 da Colônia Paranavaí em área do município de Loanda entre o Porto São José e o então distrito de São Pedro do Paraná, incluindo a já titulada área de 1.200 alqueires. Acreditava o referido técnico que as terras eram devolutas quando na verdade estavam ocupadas por colonos que haviam adquirido títulos da imobiliária Terras Colonização Paranapanema Ltda. Para não prejudicar os colonos, o governador Moysés Lupion “relutou” em conceder o título definitivo a Rocha Loures sobre os 4.000 alqueires. Somente em 1959 é que seu vice-governador Guataçara Borba Carneiro, aproveitando-se de viagem internacional de Lupion, assinou o título não levando em conta aqueles que já possuíam títulos na mesma área de terras.

No final de 1963, depois de 12 anos de colonização, quando os colonos já se faziam em maior número, em torno de 1.000 famílias assentadas em pequenas propriedades de 5, 10, 15 e 20 alqueires, o Desembargador Rocha Loures, de posse do título definitivo, achou-se no direito de aumentar a guarda sobre a área ameaçando todos de despejo (ESTADO DO PARANÁ, 1964).

\section{A revolta dos colonos}

O ano de 1963 terminou para a microrregião extremo noroeste do Paraná com a criação do município de São Pedro do Paraná que em 29 de novembro daquele ano se desmembrou de Loanda e aguardava pelo final de 1964 (14 de dezembro) para sua oficialização, o que aconteceria apenas com a posse do primeiro prefeito (em 30 de dezembro) a ser escolhido nas eleições municipais marcadas para o dia 15 de novembro daquele ano. Antes, porém, a população da localidade São Pedro do Paraná que pertencia à Loanda, assim como a de todo o Brasil, teria que passar pelo agitado ano de 1964, a 
começar pelo golpe civil-militar de $1^{\circ}$ de abril que depôs o presidente João Goulart e cancelou suas reformas de base, entre elas, a reforma agrária.

Curiosamente, no dia $1^{\circ}$ de janeiro do fatídico ano, sob o clima das reformas e em meio às boas-vindas ao ano de 1964, o matutino local “Jornal de Loanda" publicava uma importante nota de repúdio dos proprietários de terras ao que seria, ironicamente, para eles: "A Reforma Agrária do Desembargador Rocha Loures". Em tom de protesto diziam na nota:

Há 12 anos nos embrenhamos por este sertão trazidos por um ideal bandeirante, vibrante, para ajudar a construir um Paraná melhor, um Brasil melhor. Adquirimos e pagamos pelas terras. Lutamos no trabalho de cada dia, sentimos a falta de nossos entes queridos, e vimos nascer e morrer nossos filhos, sem assistência médica...

Produzimos para o Paraná porque para nós, pouco restou, a não ser a terra, a "terra que é nossa", e as plantações que agora produzem o fruto merecido que é para nossos filhos.

Há alguns anos no governo Moysés Lupion recebeu o Desembargador Rocha Loures uma área de terra... a título de compensação justamente a que era e é nossa, toda já ocupada por pequenos proprietários. Sabemos lá que compensação [...]. Esse mesmo documento ressalva o direito de posse dos que já estiveram na dita área, ou que tivessem adquiridos de boa-fé, etc. etc.

Recebeu o senhor Rocha Loures um presente de grego, um presente frio, que o mesmo desembargador Rocha Loures quer fazer esquentar através de uma justiça cega, porque não quer ver nossos cafezais, que nossas culturas já são de mais de 10 anos.

Parece que a solução é desapropriação, porque a justiça não quer reconhecer que é nossa, a terra onde labutamos há 12 anos. Mas isso é o que o senhor Rocha Loures quer: é dinheiro sonante por um documento que é bem claro. $\mathrm{O}$ mesmo recebeu do Governo do Estado uma área de terra, a que não tem direito porque já está ocupada e fim do espetáculo.

Seja lá como for dada a solução, a realidade é que a terra é nossa e não saímos dela.

Bem que somos contra a reforma agraria da qual os "grandes" sempre falam. Queremos somente o fruto de nosso trabalho honesto.

Estamos com o apoio das populações de nossas cidades e de cidades vizinhas. Estamos com o apoio de nossas consciências.

Dizem que a vida é uma luta. Lutar é viver!

"Nós lutamos por aquilo que é nosso".

Os proprietários (JORNAL DE LOANDA, Loanda-PR: $1^{\circ}$ de janeiro de 1964, p. 1, Apud: ESTADO DO PARANÁ, 1964, fl. 5).

O jornal anunciava o início das mobilizações dos colonos contra as pretensões do Desembargador Rocha Loures e que no começo de 1964 chegava a seu ponto mais alto. Segundo depoimento do prefeito de Loanda, à época Francisco de Assis Pinheiro, o movimento eclodiu quando o morador da localidade Porto São José de nome Sebastião Gonçalves da Silva, dizendo-se delegado da localidade e obedecendo ordens do Desembargador, comandou um grupo de jagunços fortemente armado na prisão de 
Revista NEP - Núcleo de Estudos Paranaenses, Curitiba, v.5, n.1, jun. 2019

trabalhadores rurais nas propriedades dos senhores Antônio Maria Rodrigues, Atílio Sangion e Diogo Ximenes, de nomes "Pedro", José Justino e Moysés Pereira de Oliveira, sem qualquer motivo justificado. Sendo que o último teria sido levado preso ao Porto São José e lá espancado pelos comandados de Sebastião Gonçalves da Silva. Isso aconteceu no dia 12 de janeiro de 1964, numa segunda-feira, quando os lotes destes proprietários foram invadidos por jagunços armados de carabina e que expulsaram os referidos trabalhadores para se apossarem das terras com casas e lavouras de café, agindo sempre em nome do Desembargador João Alves da Rocha Loures (ESTADO DO PARANÁ, 1964).

No dia seguinte, 13 de janeiro, temendo maiores retaliações, os mesmos agricultores e outros da área em litigio, em torno de 300 pessoas, resolveram agir convocando uma reunião em Loanda com o prefeito e com o presidente da câmara Hugo Roberto Acorsi. Surgiu da reunião a iniciativa de fazer um abaixo-assinado ao Delegado Regional de Polícia, Tenente Coronel Arivonil Fernandes dos Santos, para que o mesmo tomasse providências junto à Polícia Especial do Estado estabelecida na comarca de Loanda. Nesse abaixo-assinado que continha 52 assinaturas os agricultores solicitavam às autoridades locais providências enérgicas no sentido de garantir a vida e a propriedade de todos os subscritos e demais proprietários (ESTADO DO PARANÁ, 1964).

A repressão aos trabalhadores, empregados dos colonos teve forte repercussão em Loanda e os comerciantes da cidade, em solidariedade aos proprietários, resolveram aderir ao movimento cerrando suas portas a partir das doze horas do dia 14 de janeiro, ficando abertas apenas a prefeitura e uma farmácia. Mas antes, ainda pela manhã do mesmo dia, quando ainda se preparava para o movimento, a comissão dos proprietários subscritos no abaixo-assinado, a pedido dos comerciantes, soltou uma nota de esclarecimento público sobre os motivos do fechamento do comércio naquele dia na qual diziam:

O comércio desta cidade estará com as portas cerradas a partir das 12 horas de hoje em sinal de protesto às absurdas pretensões do Desembargador Rocha Loures e pelas violências praticadas por seus jagunços contra legítimos proprietários de terras em Loanda (A Comissão. Loanda, 14 de janeiro de 1964, apud: ESTADO DO PARANÁ, 1964, fl. 5).

O movimento eclodiu a partir das 12 horas do dia 14 de janeiro como repúdio às pretensões do Desembargador Rocha Loures não indo aos extremos por conta da 
Revista NEP - Núcleo de Estudos Paranaenses, Curitiba, v.5, n.1, jun. 2019

intervenção do prefeito e do presidente da câmara que, uma vez entendendo as razões dos proprietários revoltados, se prontificaram em apoiá-los no que fosse necessário. Informaram as referidas autoridades que todos os moradores da área litigiosa que constituíam o município de Loanda e do recém-criado município de São Pedro do Paraná e de seu distrito Porto São José, bem como do vizinho município de Nova Londrina e de seu distrito Marilena e que também abrangiam partes das terras em litigio, estavam dispostos a pegarem em armas para defender seus direitos patrimoniais caso fosse concretizado o que eles mais temiam, o despejo! Alguns deles já falavam que estavam dispostos a qualquer coisa para defenderem seus lares, suas propriedades e suas vidas. Outros, no entanto, os mais exaltados, diziam que se fossem despejados iriam a Curitiba, capital do Estado, assassinar o Desembargador (ESTADO DO PARANÁ, 1964).

Diante dos fatos que foram relatados no abaixo-assinado enviado pelos agricultores ao Tenente-coronel Arivonil Fernandes dos Santos, Delegado Regional de Polícia de Loanda, este determinou ao Capitão Adélio Mousinho de Oliveira, Delegado Especial de Paranavaí, que se deslocasse à localidade Porto São José onde eram mantidos presos os empregados dos agricultores para apurar os fatos.

A providência tomada pelo Capitão Adélio Mousinho de Oliveira ao proceder na investigação foi submeter o trabalhador Moysés Pereira de Oliveira, vítima de tortura, a exame de corpo de delito cuja perícia, segundo ele, não constatou "uma só lesão" para formalização de inquérito. Ao contrário, de acordo com a versão do Capitão, teria sido ele - Moysés Pereira de Oliveira - e outros trabalhadores rurais que teriam invadido a área do Desembargador Rocha Loures de 1.200 alqueires de terras no Porto São José que, por direito, lhe pertence e ali deram início à construção de casas para fazerem posses e invadir o referido imóvel. E que esse fato teria sido levado ao conhecimento do "subdelegado" em exercício no Porto São José - Sebastião Gonçalves da Silva - o qual os deteve sim, segundo o Capitão, apenas para averiguações, nascendo daí a duvidosa versão dos agricultores de que Moysés Pereira de Oliveira, empregado de Diogo Ximenes, teria sido torturado (ESTADO DO PARANÁ, 1964).

Ou seja, na versão do Capitão Adélio Mousinho de Oliveira os invasores eram os posseiros! Porém, sabe-se que estes já se encontravam nas terras antes da concessão delas ao Desembargador. Dois anos depois da repressão que resultou na revolta dos colonos, em 1966 o governador do Paraná desapropriou 1.000 alqueires de terras em torno da localidade Porto São José enquanto que a disputa pela área dos outros 3.000 alqueires 
Revista NEP - Núcleo de Estudos Paranaenses, Curitiba, v.5, n.1, jun. 2019

continuou sub judice até o ano de 1976 quando também foi desapropriada pelo governo do Estado mediante indenização ao Desembargador enquanto os colonos receberam títulos provisórios do governo para continuarem na posse das terras.

Antes, porém, o governo do Paraná teria ainda que travar outra disputa judicial contra Rocha Loures. O Desembargador requisitou na justiça uma indenização pelas "benfeitorias" que ele teria realizado na área do Porto São José, mas o advogado do Estado provou à época que o Desembargador não havia feito nenhuma das benfeitorias e de que as mesmas até então existentes foram realizadas pelos colonos que há muito tempo ocupavam e cultivavam aquelas terras.

\section{Os agentes da grilagem e seus crimes}

A disputa pelas terras do grilo "Areia Branca do Tucum” deixou um saldo violento de crimes como extorsões, roubos e assassinatos. Um caso emblemático foi o do advogado Raphael Veríssimo Azambuja. Oriundo do Estado do Rio Grande do Sul e primo do escritor Érico Veríssimo, Azambuja havia comprado uma fazenda da imobiliária Terras Colonização Paranapanema Ltda próxima a Nova Londrina e Marilena e que, depois, em virtude de desentendimentos com José Volpato, dono da colonizadora, acabou morto por ele. Quem dá detalhes deste crime é o jornalista David Arioch em matéria de 8 de fevereiro de 2015 publicada pelo jornal "Diário do Noroeste" de Paranavaí. Segundo Arioch, o assassinato aconteceu em 7 de julho de 1962 quando Volpato, percebendo que as terras que tinha vendido a Azambuja "conquistaram um alto valor de mercado em pouco tempo", exigiu dele uma "compensação financeira". Ao se recusar a pagar, "afinal o negócio já estava feito", Volpato, acompanhado de dois jagunços e de seu motorista dirigiu-se ao escritório de Azambuja em Marilena e desferiu cinco tiros à queima-roupa contra ele (ARIOCH, 2015). Por causa do crime Volpato foi levado à júri popular em 13 de setembro de 1962, mas absolvido sob alegação de "legítima defesa".

Durante a disputa pelas terras na Areia Branca do Tucum destacaram-se alguns nomes que ficaram famosos na microrregião, entre eles figura o de João da Silva Ladeira, vulgo "Barranco". Oriundo do vizinho Mato Grosso do Sul (que na época ainda fazia parte do Estado de Mato Grosso) de onde saiu foragido da polícia daquele Estado pelo crime de assassinato do major Saens de Matos, "Barranco" era tido pelos moradores de 
Revista NEP - Núcleo de Estudos Paranaenses, Curitiba, v.5, n.1, jun. 2019

Loanda como um dos jagunços de Rocha Loures por atuar como "segurança" em uma área de 600 alqueires de terras do grilo do Desembargador despejando posseiros e roubando seu estoque natural de madeira. Depois dos "serviços" prestados o Desembargador tentou se livrar do vínculo que possuía com o criminoso dizendo em depoimento ter com ele apenas um contrato de parceria para a derrubada da mata dos 600 alqueires, serviço que aquele teria realizado em troca da extração da madeira de lei existente. Depois da revolta dos colonos em 14 de janeiro de 1964 "Barranco" ficou por um longo período desaparecido do grilo, mas no começo de 1966 foi visto novamente em Loanda na presença de Rocha Loures, apesar do mesmo negar qualquer vínculo com o jagunço.

Outro nome da grilagem é o de Sebastião Gonçalves da Silva, o mesmo que se passou por delegado no Porto São José quando da prisão dos trabalhadores que resultou na revolta dos colonos em 1964, mas todos do lugar tinham Gonçalves da Silva como jagunço do Desembargador. A prova desse vínculo vem de uma ação trabalhista interposta por ele no fórum de Loanda em 1968 em que alega ter prestado "serviços" por quinze anos na fazenda que o Desembargador possuía na localidade do Porto São José à margem esquerda do rio Paraná.

Além destes, outros nomes vêm da família do advogado Alípio Carlos Correia Porto Leite e de seus agregados. Em virtude de sanhas cometidas durante o processo de colonização da Areia Branca do Tucum, a família Porto Leite foi considerada pelas autoridades do Estado como o "cravo" da região. Dizem que Alípio e "Léo" Porto Leite - pai e filho - formaram na localidade rural Leoni, no município de Loanda, uma área de mil alqueires de pastagens comprando ilegalmente terras de antigos posseiros. No local residiam outros cinco jagunços da família, a saber Waldemar da Silva, vulgo "Bila", "João Bila”, “Joel”, Antônio Batificia e "Domingos", todos contratados pelo advogado que também era delegado no Porto São José e chefe do "bando".

Além de repressão aos posseiros, os jagunços da família Porto Leite atuavam na extração ilegal de madeira. Neste sentido, foram muitas as queixas registradas ao Dr. Ciro Crema, Juiz de Direito da Comarca de Loanda, por aqueles de que a polícia estava acobertando os "madeireiros", inclusive o próprio "Barranco". Waldemar da Silva - o "Bila" - havia mandado roçar e extrair madeira em dois lotes do "grilo" sem que nada tivesse sido feito para impedi-lo. A prova desse e de outros roubos de madeira da área desapropriada foi registrada por Geraldo B. Farias, oficial de justiça da comarca de 
Loanda:

\begin{abstract}
Dirigimo-nos aos lotes $\mathrm{n}^{\circ} 218,213$ e 214 e aí verificamos que estavam retirando madeiras do lote 218 , encontrando naquele lote caminhões da madeireira São José da cidade de Nova Londrina, caminhões estes que estavam carregados e que fizemos descarregar, madeira num total de 28 toras e que foi vendida por Waldemar da Silva ou "Waldemar Bila", sendo informado pelo mesmo Waldemar que uma parte da madeira foi vendida pelo Dr. Alípio Carlos Porto Leite à Serraria Progresso, nesta cidade, madeira num total de 65 metros cúbicos, conforme informação do proprietário da referida Serraria. A madeira dos lotes 213 e 214, foi vendida por João da Silva Ladeira, vulgo "Barranco", e retirada pela madeireira São José. Deixamos de verificar a madeira na Serraria por esta não estar localizada nesta comarca (as.) Geraldo B. Farias Oficial de Justiça (apud: ESTADO DO PARANÁ, 1966, fl. 15).
\end{abstract}

Segundo informações de Guilherme Eumann, encarregado do escritório do Conselho de Desapropriação e Colonização em Loanda, mais de cem toras de madeiras de lei foram retiradas da área desapropriada por Gumercindo Antônio Ramos autorizado por Léo, filho do delegado Alípio Porto Leite.

Queixavam-se os colonos de que os jagunços que iam com caminhões "retirar" madeira faziam um tiroteio no meio do mato para intimidar os trabalhadores e que eles sempre tiveram a cobertura da "polícia" que se beneficiava recebendo parte da madeira, fruto do roubo, para construir casas e cercas em suas propriedades. A corrupção ia da polícia local e chegava às autoridades encarregadas da desapropriação como Albano David - Inspetor de Terras de Londrina - depositário das terras em litígio e que, apesar de ser chefe do escritório do DGTC em Loanda, nunca tomou providências sobre o caso e nem solicitou o auxílio da polícia por conivência com os infratores.

O conluio policial com o Desembargador Rocha Loures era algo que indignava a todos da região uma vez que o delegado e os policiais locais eram totalmente submissos a ele e isso ficou mais evidente ainda quando no começo de 1966 o subtenente Zózimo da Silva pediu ao Delegado Regional de Paranavaí que fosse transferido para o Porto São José, a pretexto de que havia se desentendido com o Delegado Regional de Loanda onde exercia sua função policial. Ao ser atendido em seu pedido de remoção, Zózimo ficou provisoriamente na casa da fazenda Rocha Loures no Porto São José, mas com a promessa do delegado Porto Leite de ganhar uma casa nova na mesma fazenda para residir com toda sua família. Em virtude dessa relação comprometedora ou no mínimo suspeita do delegado e do subtenente com o Desembargador houve denúncias seguida de intervenção do Comando Geral da Polícia Militar do Estado. Zózimo acabou afastado de suas funções policias no Porto São José e recolhido em Paranavaí, onde ficou à disposição daquele 
Revista NEP - Núcleo de Estudos Paranaenses, Curitiba, v.5, n.1, jun. 2019

Comando.

Naquele mesmo ano de 1966, da desapropriação, o subdelegado do Porto São José era João "Mato Grosso", outro jagunço a serviço do delegado Porto Leite e que também havia sido contratado por ele para a derrubada de mato e extração ilegal de madeira em 50 alqueires da área desapropriada. Na ocasião o delegado Porto Leite usou parte da madeira extraída ilegalmente para construir a subdelegacia do Porto São José.

Em suma, o grilo de terras e o roubo de madeira estavam institucionalizados na Areia Branca do Tucum por autoridades do Estado representadas na área pelo “desembargador-grileiro" e por autoridades policiais locais ligadas a ele em que mais atuavam como jagunços que segurança pública, função para a qual foram nomeadas.

\section{Conclusão}

Os casos dos grilos Apertados e Areia Branca da Tucum, não foram fatos isolados na história do Paraná, toda a violência gerada pela disputa das terras nesta região acarretou em vítimas fatais.

Desta forma não podemos deixar as vozes e as ações do passado no esquecimento, pois a luta que travaram para não perder suas posses para aqueles que detinham mais poder, pode servir de inspiração para todo aquele que se encontra diante das injustiças causadas por aqueles que deteem o poder.

O apoio dos comerciantes da cidade de Loanda mostra que as pessoas não são indiferentes ao sofrimento alheio, as famílias atingidas pela violência na disputa por estas terras do noroeste encontraram não só a solidariedade dos habitantes da cidade como também do próprio Estado, não porque este se solidarizou com os pequenos proprietários, mas para não ter mais prejuizos causados pelos grileiros que usurpavam não só as terras do próprio Estado, como de particulares.

Portanto, pesquisar e mostrar os fatos ocorridos no processo de colonização da região noroeste do Paraná é dar voz aqueles que verdadeiramente deram seu suor e muitas lágrimas não para colonizar esta terra, mas sim reocupá-la, pois que estas terras nunca foram o "espaço vazio" propagado na fala dos poderosos, desde as populações indígenas que foram sendo expusas desta região, esta terra vem sendo banhada com o sangue daqueles que queriam dominar este espaço. 
Revista NEP - Núcleo de Estudos Paranaenses, Curitiba, v.5, n.1, jun. 2019

Referências

ARIOCH, David. O assassinato de Raphael Azambuja na Areia Branca do Tucum. Coluna: "Histórias do Noroeste", Jornal "Diário do Noroeste". Paranavaí-PR, 8 de fevereiro de 2015.

ARQUIVO PÚBLICO ESTADO DO PARANÁ. Relatório emitido por João Batista Lopes, Chefe da 14. ${ }^{a}$ Subdivisão Policial, à Secretaria de Estado de Segurança Pública do Paraná em 16 de janeiro de 1964. Curitiba-PR: Pasta da DOPS "Questão de Terras - Areia Branca do Tucum”, documento nº 03468, fls. 01 a 11.

ARQUIVO PÚBLICO ESTADO DO PARANÁ. Relatório emitido por Neylor Vasconcelos de Andrade, Chefe da Divisão Policial do Interior, à Secretaria de Estado de Segurança Pública do Paraná em 4 de julho de 1966. Curitiba-PR: Pasta da DOPS “Questão de Terras - Areia Branca do Tucum”, documento n 03468, fls. 12 a 17.

História de Loanda. Disponível em: http/www.loandaonline.com.br. (acessado em: 15 Maio. 2007).

ITCG - Instituto de Terras, Cartografia e Geociências. Relatórios: Histórico do Grilo “Apertados" e Histórico do Grilo “Areia Branca do Tucum”. Curitiba: ITCG, s/d.

ITCG - Instituto de Terras, Cartografia e Geociências. Relatório: Histórico do Grilo Apertados. Curitiba: ITCG, 1950.

ITCG - Instituto de Terras, Cartografia e Geociências. Relatórios: Histórico do Grilo “Areia Branca do Tucum". Curitiba: ITCG, 1952.

ITCG - Instituto de Terras, Cartografia e Geociências. Relatórios: Histórico do Grilo "Areia Branca do Tucum". Curitiba: ITCG, 1953.

KUNHAVAliK, José Pedro. "Bento Munhoz da Rocha Neto: Trajetória Política e Gestão no Governo do Paraná". In: OLIVEIRA, Ricardo Costa de (org.). SALLES, Jefferson de Oliveira. A Construção do Paraná Moderno: políticos e política no Governo do Paraná de 1930 a 1980. Curitiba: SETI, 2004.

OLIVEIRA, Ricardo Costa de. "Notas sobre a política paranaense no período de 1930 a 1945". In: OLIVEIRA, Ricardo Costa de (org.), SALLES, Jefferson de Oliveira, KUNHAVALIK, José Pedro. A Construção do Paraná moderno: políticos e política no Governo do Paraná de 1930 a 1980. Curitiba: SETI, 2004.

PARANÁ. DEAP - Departamento Estadual de Arquivo Público. Fundo Dops - dossiês: Dossiê 543 cx 60. Dossiê 163 cx 199. Dossiê 2050 cx 232.

ROMPATTO, Maurílio (org.). História e memória da colonização do noroeste do Paraná: os casos de Paranavaí, Nova Londrina e Loanda. Maringá-PR: Editora Massoni, 2012.

SCALIANTE, Hortência D. Violência e conflitos políticos no processo de colonização da região noroeste do estado do Paraná: os casos dos grilos "Apertados" e "Areia Branca do Tucum" (1950-1970). Maringá-PR: Universidade Estadual de Maringá - 
UEM, Dissertação de mestrado, 2010.

SOARES DA SILVA, Paulo Marcelo. História de Paranavaí. Paranavaí-PR: Fundação Municipal de Cultura, 2014.

Recebido em: 25 abr. 2019.

Aceito em: 10 jun. 2019. 